Published by the University of KwaZulu-Natal https://journals.ukzn.ac.za/index.php/JICBE (C) Creative Commons With Attribution (CC-BY)

Journal of Inclusive cities and Built environment. Vol. 2 Issue 1

How to cite: I.M. Raimundo. 2022. African Migrants toward Inclusive Growth in Mozambique: A case study of the city of Maputo. Conference Proceedings for International Symposium on Inclusive-Cities: Achieving Inclusive Cities Through A Multidisciplinary Approach, 2021 28-30 June. Journal of Inclusive cities and Built environment. Vol. 2 Issue 1, Pg 70-79.

\title{
AFRICAN MIGRANTS TOWARD INCLUSIVE GROWTH IN MOZAMBIQUE: A CASE STUDY OF THE CITY OF MAPUTO
}

\author{
By I.M. Raimundo
}

Published 31 January 2022

\begin{abstract}
Migration African scholars have argued that the Migration of Africans is occurring within the continent. That Migration can either be intra-regional or inter-regional. South Africa and Northern Africa constitute the core for all African immigration flows; the so-called intra-immigration is made of migration chains such as within the Maghreb region, west, east, and southern Africa. Historically, Mozambique has sent labor to South Africa in plantations and mining for more than two centuries, while on the other hand, it was seen as a producer of refugees, a Portuguese-speaking country, and lower levels of Development indicators. As a consequence, it was a country not desirable to be or to settle. In the last two decades, the stigma on immigration towards Mozambique is deconstructed because of the businesses and jobs opportunities that arose in the country for the boom era of mining, including oil, gas, and coal. The current geography of immigration is made of a multicultural of people from all over the world. A chain of new shops made of construction material, spare car material, barber, boutiques, groceries, and liquor shops are widely seen in Maputo. Most in containers and owned mainly by African migrants, Chinese, and Mozambicans. African migrants have been portrayed as those who do not add any value to any economy. Instead, they are job stealers. However, the study has demonstrated African's contribution to economic growth as they give jobs and regularly pay rents and taxes. The study is part of MIAG (Migration for Inclusive African Growth) ${ }^{1}$ results where interviews and surveys were used.
\end{abstract}

\footnotetext{
The MIAG team contains academics from the Open University, UK, and a partner organisation in each of the four African countries of focus: Centre for Migration Studies, University of Ghana (Ghana), African Migration and Development Policy Centre (AMADPOC, Kenya), Center for Policy Analysis, Faculty of Arts and Social Sciences, Eduardo Mondlane University (Mozambique) and Network of Migration Research on Africa (NOMRA, Nigeria).
}

Inês M. Raimundo: Eduardo Mondlane University, Faculty of Arsta and Social Sciences, Centre for Policy Analysis and Department of Geography. Maputo, Mozambique. 


\section{INTRODUCTION}

One of the amazing things that social and human sciences have is adjusting concepts as far as new results are found with solid arguments, and the acceptance that the concept varies according to the socio-cultural condition. Also is the ability to incorporate concepts regardless of the origin of the individuals and qualifications. The rationality on that is that all opinions matter. Both concepts are malleable or versatile and used by a range of social and human sciences such as economists, sociologists, historians, and migration experts. Regarding this, the Inclusive growth and migrations object of this analysis are concepts that asked for the context of Maputo city. Without surprise, the research on Migration for Inclusive African Growth (MIAG) project demonstrates commonalities on definitions and some differences.

Besides being a traditional sending country via labor migration into South Africa, Mozambique has witnessed, latterly, a growth of immigration, so it was of interest to understand this new flow of Migration. Interviews and surveys were conducted in Maputo city from some African citizens. The selection of some of these citizenships was based on the new pattern of immigration to Mozambique, such as made of Africans from the Great Lakes of Africa (Burundi, Democratic Republic of Congo, and Rwandan), Nigeria, Senegal, and the Horn of Africa. This wave of immigration is different from the traditional one made of Southern African countries or the ancient Migration from Portugal (former colonial country), India, and China. The paper is about the contribution of African Inclusive growth based upon responses from immigrants themselves and the Mozambican perspective as a hosting country. Lastly, the main question was: To what extent do immigrants contribute to inclusive growth?

\section{SOME METHODOLOGICAL ISSUES}

Studying people on the move, particularly those in a hosting country, an irregular or stereotype towards immigrants, is a challenge. Studies (Rocha-Trindade,
2015; Raimundo et al., 2021) state that the situation becomes worse as it is almost impossible to identify the various components or segments of people in a move, mainly to immigrants who cross international borders without declaring in which circumstances did they cross such borders neither their purposes in hosting country, such as Mozambique. That situation worsens if it is considered that Africans do not consider themselves as a migrant, they consider belonging to the same community and separated by colonialism (Matusse 2009, Raimundo \& Raimundo 2015; 2017; Raimundo et al.,2021).

As mentioned earlier, this paper results from data collected within the scope of Migration for Inclusive African Growth. Data collection occurred during the year 2020 amid the Covid pandemic. Mozambique adopted in the year of 2020 three States of emergency marked by lockdown and later by curfew or limitation of movements and contacting either target group or Mozambicans themselves. Additionally, to this set of limitations, other limitations were Nigerians refused to be considered Nigerians, instead called people of Biafra. In the meantime, citizens of Burundi, the Democratic Republic of Congo, and Rwanda feared to respond to questions because most of them are living as irregular migrants in Mozambique. Their status does not allow them authorization either to live in Mozambique or to do business. Regarding interviews and surveys, telephone calls and face-to-face interviews undertook where possible, making this paper feasible.

\section{THE CONTEXT OF THE STUDY}

Until about two decades, Mozambique was unidirectional outbound Migration to neighbouring countries, mainly to South Africa, Malawi, and the formerly known country, Swaziland, currently named E-Swatini, in response to labour migration and political instability, and natural disaster. However, with the signature of the General peace Agreement in the year 1992 between the Government of (Mozambique Front Liberation) and RENAMO (National Resistance of Mozambique) that imposed the end of hostilities in the country, the country started to receive a new movement of migrants, in opposition to historical one made of Portuguese, Indians, and Chinese. Also, the country registered the circular Movement of immigrants from some southern African countries that border Mozambique, mainly Malawi, Tanzania, Zambia, and Zimbabwe. This new movement pattern of immigrants represents new geography of origin made of immigrants from the Great Lakes Region of Africa, Western Africa, and the Horn of Africa. Within the same period, the country also received immigrants from Brazil, Lebanon, and Turkey. The facts mentioned above reveal significant changes in migration trends in Mozambique. From a longstanding historical outbound migration to neighbouring countries, particularly to South Africa, it became an in-bound global Migration, emphasizing the countries mentioned above. It is noted a set of a multiplicity of factors that explain that change, of which the following stand out:

\section{- the propelled boom of mineral resources; \\ - the openness of the country to foreign investments; \\ - the economic and political crises in Zimbabwe that resulted into out-migration toward Mozambique; and \\ - xenophobic attacks in South Africa.}

These facts demonstrate the existence of a new geography of international Migration, as from the late 1990 decade, Mozambique became a hosting country of immigrants that till then, it did not have the status of a destination country for relocation purposes.

With a growing number of immigrants demonstrated by both official sources, namely, the National Institute for Statistics of Mozambique and the National Service of Migration reveals that Mozambique has transited from a traditional outbound migration to a simultaneous outbound, inbound, and transit migration country, which suggests new geography of international Migration. 
MIAG project (https://www.open.ac.uk/researchprojects/migration-inclusive-africangrowth), is responding to the challenge by developing a robust conceptual framework that will link Migration to inclusive growth. In giving data collection was made about the concept or definition of Migration, migration experience, circumstances or causes of Migration, integration and challenges faced by migrants, the importance of migration policy, and the role of Migration to inclusive growth. MIAG team defined six nationalities plus Mozambique, namely Burundi, China, India, Nigeria, Portugal, and Rwanda. Nevertheless, for this paper, African migrants constituted the target group. As mentioned above, the purpose of including others not part of the study is to deconstruct the hypothesis that African migrants are development spoilers or are not assets for the hosting country.

\section{STUDY AREA AND STUDY OBJECTIVES}

Like the MIAG project, the aim of the study are::

- To understand the meaning of Inclusive growth under the perspective of immigrants

- To ascertain the contribution of African immigrants to inclusive growth.

The study area is Maputo, the capital of the Republic of Mozambique (map 1).

Map 1: Maputo in the Context of the Republic of Mozambique

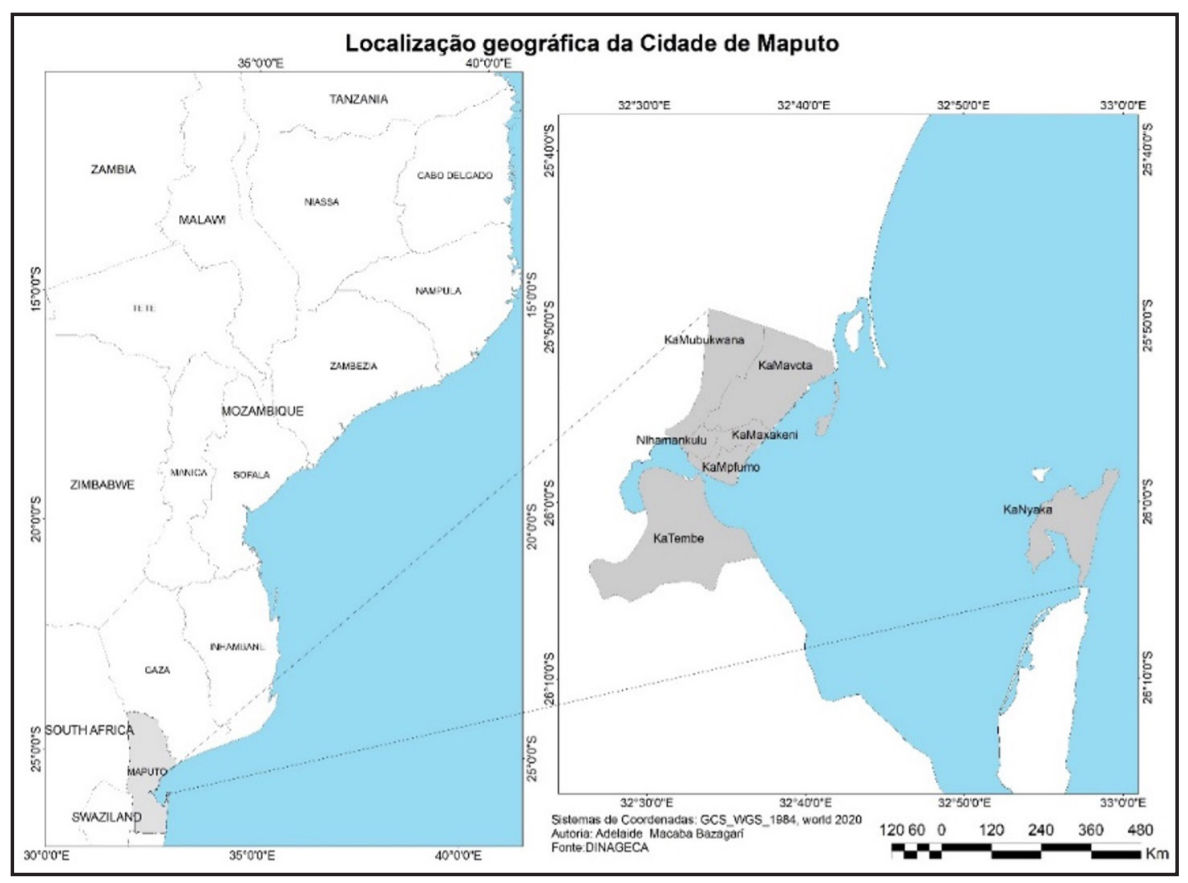

Table (1) indicates the people who were part of the study either as interviewees or inquired.

Table 1. Interviewed and inquired by sex

\begin{tabular}{|l|l|l|}
\hline \multicolumn{2}{|c|}{ Survey } \\
\hline Sex & No & $\%$ \\
\hline Female & 85 & 23.16 \\
\hline Male & 278 & 76.94 \\
\hline Total & 367 & 100 \\
\hline
\end{tabular}

Source: MIAG data basis and individual interviews

\section{THE UNDERSTANDING MIGRATION AND INCLUSIVE GROWTH}

Migration trends indicate the emergence of a new global migration system in the past 50 years and the Age of Migration (Castles \& Miller 2009). That phenomenon has seen a tremendous increase in global and local connections' magnitude, density, velocity, and diversity. Migration brings challenges and actors who permanently deal with the phenomenon. None of the actors can deny his or her role in this process.

Mozambique is one of the Southern African countries where all causes of Migration do happen. The country is under crossfire factors, namely military instability and natural disasters (Raimundo 2020), while it is continuing to send its labor force to mining and plantations of South Africa (Cikanda \& Raimundo 2017; Muanamoha \& Raimundo 2020; Muanamoha 2010). Besides being a traditional sending country via labor migration into South Africa, Mozambique has witnessed, latterly, a growth of immigration, mainly from the Great Lake Region of Africa and not only as well as from Asia such as China, Bangladesh, Pakistan, Turkey to name same (Raimundo, Bazagari \& Raimundo 2021). This new wave of immigration results from Raimundo \& Raimundo (2017) the calling due to the discourse of natural resources discovery. In an unpublished paper of Raimundo (2018), there is a clear Division of Labour made of immigrants, including Africans, towards mining areas. There is intensive artisanal mining in all countries. Manica is captured by Zimbabweans, Malawians, Zambians, and some Nigerians while Provinces of Zambezia and Nampula by Bengalis, Congolese, Rwandese, Burundians and Chinese, and latterly Cabo Delgado by Tanzanians, Kenyans, and Nigerians.

Raimundo (2021; 2020; 2013) points out that Mozambique was chosen as a final destination for refugees or as a transit country to South Africa. Several reasons have made Mozambique be a final destination. These includes the peace after 16 years of armed conflict that opposed FRELIMO (Mozambican Front Liberation) and RENAMO (Mozambican 
National Resistance); the people living in the refugee camp are not confined to camp or settlement, their freedom of Movement is not restricted, and importantly they are free to seek for jobs including doing businesses such as trade and agriculture; family and community ties or economic opportunities (due to mining opportunities); and those who have settled in the refugee camp can quickly bring their family member to join them.

Factors that has facilitated the entries in Mozambique is are: i) The open door visa to enter the country can be getting in any entry port; ii) the borders are not constantly monitored, and even though the existence of the border police there are many places that people can use to enter. Some migrants who cross borders illegally have been deterred and labeled as illegals trafficked or smugglers of people. Nevertheless, migrants in transit because their will is to reach South Africa; some cannot afford to live in Mozambique because of the accusation of witchcraft (inside and outside of the Refugee camp), the language barrier; the bureaucracy for getting papers; the language since the official language of Mozambique is Portuguese, and most of the migrants are coming from Francophone, Anglophone or Arabphone countries. In the meantime, there is some jealousy due to the success of some refugees in businesses.

In any study or publishable document, concepts and definitions are compulsory as readers need clarification about the meaning of any work. However, defining Migration is still a challenging process, as Peixoto (2004) points out about difficulty studying Migration. The hardship is because Migrations studies are so cross-cutting to the extent that they can be perceived as "nobody's land," which makes it easier to establish interdisciplinary (also discussed by Castles \& Miller 2009) trans-disciplinary perspectives. Furthermore, Peixoto states that Migration as a scientific subject is more linked with Geography and Demography; perhaps, according to this author, spatial or territorial impacts are witnessed daily.
Therefore, one of the questions posited in this field of knowledge is to explain which concept is used? For instance, in census data, migration is based on the length of residence in the destination area. The timeframe is one year and five years. Regardless of this beacon of one year and five years, local people still call those not part of that place a migrant.

On further discussions, the definition also includes discoveries of topics that should be included in the definition or the study. De Has (2010), in his work on Migration and development, stresses that the debate should look at the shift of paradigm in social and development theory. Further, the author calls attention of the need to integrate insights from the new economics of labor migration, livelihood perspective, and transnational perspectives in migration studies. That perspective of De Has is part of the ancient discourse that Migration is not a simple demographic variable is far more than that. There is a global sense that everybody can define Migration because it is part of us, and any individual is a potential migrant. The concept varies more because of the mutation of factors that cause it. Further change countries' roles either is receiver or sender or both situation, which is the case of Mozambique.

However, in this written-on migration causes of Africa clearly, it is witnessed the emphasis given to people in search of better conditions or livelihood; people who are fleeing political instability or environmental issues. Nevertheless, very few written is about Africans who are investors in other African countries or contribute to inclusive growth.

Giving a concept or making a definition is a challenging exercise. Thus, for this paper's purpose, the easiest thing was to borrow a concept or definition from institutions whose role is to protect and assist migrants. The IOM glossary (2011) defines Migration and International Migration as the Movement of a person or a group of persons who moves within international borders or States. It is a population movement, encompassing any Movement, whatever its length, composition, and causes; it includes the Migration of refugees, displaced persons, economic migrants, and persons moving for other purposes, including family reunification. Then this paper, the period or length of stay either in Mozambique or in Maputo city where such person was the target as a migrant was not considered. Still quoting the IOM glossary, international Migration is the Movement of persons who leave their country of origin, or the country of habitual residence, to permanently or temporarily in another country. An international frontier is, therefore, crossed.

By the year 2010, the city of Maputo, like other African cities, was markedly an unequal city where about $70 \%$ of its population live in underserved wards, and about $70 \%$ rely on informal activities (UN-Habitat 2010); this means gaps between those who are better off with the poor. Further rural Migration is the one phenomenon that increases pressure on infrastructure with high possibilities of increasing gaps between poor and wealthy city dwellers. What this has to do with Migration and inclusive growth? There is a lot as the poor can take to their tables anything they want to eat or buy. From a piece of chicken to a cup of rice or a teaspoon of tea or sugar, they can feed their households daily. African Migrants brought this system of selling by pieces or small containers. OECD attests that inclusive growth is a response to inequalities that put our world at risk. Inequalities can be the cause of terrorist attacks as it is happening in one of the Mozambican provinces (Feijó 2021; 2020; CDD 2020; CIP 2020).

The literature recognizes that inclusive growth has a broader concept. However, the main issues brought in this concept is inclusion of all and benefit that all citizens of a given society can enjoy and opportunities access. Furthermore, an economy is a partnership between producers and consumers within a structure of production, market, income, and labor market. Lastly, inclusive growth is also the most cross-cutting concept that fits in any acknowledgment area. Primarily it has been linked with the economy, Development, GDP, and minor on Migration. Given that beyond the migration phenomenon, there are migrants, the paper assesses the contribution or the extent of that 
contribution of African countries for inclusive growth.

So, what is inclusive growth? OECD (2021) defines inclusive growth as economic growth distributed relatively across society and creates opportunities for all (OECD 2021). However, that definition excludes those who are not in a formal system, ie. Those who are counted in GPD or formal statistics to be part of the economy. It is against this background that the paper tries to incorporate the contribution of African Migration to inclusive growth. Through their work, these immigrants contribute to the economy and make products circulate between producers and consumers through their work. Also, their businesses hire Mozambicans either as loaders, clients-callers, shop sellers, dealers with authorities, interpreters, and shoppers, including crossing borders to South Africa or Eswatini as most the immigrants cannot cross borders legally because of their irregular permanence in Mozambique.

\section{THE DEFINITION OF INCLUSIVE GROWTH BY IMMIGRANTS THEMSELVES AS BY THE HOSTING COMMUNITIES OF THE CITY OF MAPUTO}

As stated earlier, the concept of inclusive growth is under construction. Thus, the immigrants and hosting communities of Maputo were given the voice to this imbricated concept. Nevertheless, the commonality of the concept is that all interviewed defines it as an economic concept. The following session is the presentation of concepts given by interviewees.

"Inclusive growth is economic growth distributed relatively across society and is everyone's participation in a country's economy. It does not matter where one comes from, as long as one works, one gets income and pays" (Burundian, Maputo 05 August 2020).

"All that I can say is that the African Continent is very rich in all kinds of resources. Inclusive growth would be the situation for all Africans to benefit from these resources. However, for the growth to be inclusive, Mozambique needs to integrate Africans" (Nigerian, Maputo 04 August 2020).

"Inclusive growth has to do with the growth of the economy of a place. It is inclusive in that it benefits everyone. For example, when there are business investments, it is assumed that communities will benefit. This inclusive growth can be measured periodically. For example, with this study, you can measure growth whether it is inclusive or not. It has many African immigrants with extensive knowledge in business, technology, mining, and language teaching. See, for example, here are Africans who speak English, French, Arabic, and Swahili" (Rwandan, Maputo, 05 August 2020).

"I think we are registered in the trade sector, we pay taxes, and as residents, we pay Annual Tax, we pay emoluments for employment contracts, we pay for the renewal of DIRE, when we are sick, we pay the clinics or hospitals, we pay household income, electricity, water, telephone, car manifest, radio tax, garbage tax, telephone, food, school fees, business, etc. So all this is money. It is money that goes into the State coffers. Imagine how many immigrants we are here. Imagine how much money comes into the country" (Burundian, Maputo 05 August 2020).

"It is everyone's participation in a country's economy. It does not matter where one comes from, but once working can pay taxes and other duties, including salaries of employees" (Burundian, Maputo 05 August 2020).

"All I can say is that the African Continent is very rich in all kinds of resources. Inclusive growth would be the situation for all Africans to benefit from these resources. However, for the growth to be inclusive, Mozambique needs to integrate Africans" (Nigerian, Maputo 04 August 2020).

"Inclusive growth has to do with the growth of the economy of a place. It is inclusive in that it benefits everyone. For example, when there are business investments, it is assumed that communities will benefit. This inclusive growth can be measured periodically. For example, with this study, you can measure growth whether it is inclusive or not. It has many African immigrants with extensive knowledge in business, technology, mining, and language teaching. See, for example, here are Africans who speak English, French, Arabic, and Swahili" (Rwandan, Maputo 5th August 2021).

"I think we are registered in the trade sector, we pay taxes, and as residents, we pay Annual Tax, we pay emoluments for employment contracts, we pay for the renewal of DIRE, when we are sick, we pay the clinics or hospitals, we pay household income, electricity, water, telephone, car manifest, radio tax, garbage tax, telephone, food, school fees, business, etc. So all this is money. It is money that goes into the State coffers. Imagine how many immigrants we are here. Imagine how much money comes into the country" (Burundian, Maputo 05 August 2020).

"Inclusive growth means everybody has a share of what a country produces. So, for example, these mega-projects will be inclusive if they allow Mozambicans to gain something. The problem is that companies eat all cake" (Senegalese, Maputo 07 August 2020).

\section{AFRICAN INTERNATIONAL MIGRATION IN MAPUTO: MIGRATION HISTORY, WHY MOZAMBIQUE AND MIGRANTS' QUALIFICATIONS?}

Muianga (2021) and Raimundo \& Raimundo (2017) agree that Africans from the Region of Great Lake of Africa and Nigeria did not choose Mozambique as a primary destination. However, under certain circumstances. They faced several challenges, such as inaccessible geographic conditions. Besides crossing the African forest, rivers, lakes, and the high probability of meeting predator animals and other kinds of danger, they have to flee from the army, armed guerrillas, and face border authorities.

Contrarily the trend on internal migration that is made of people with low skills and education the African migrants interviewed during the study are well educated and made of accountants, interpreters, managers, caretakers, 
psychology, natural gas technician, tailoring, counseling, electronic engineers, schoolteachers, high school degrees and other relevant qualifications. They also have some abilities such as stylists, barbers, clothes designers, to mention some. So are people if they are allowed to contribute more than what they are currently doing.

\section{MIGRATION HISTORY: WHICH COUNTRIES HAVE THEY MOVED FROM AND REASONS FOR MIGRATION?}

Rabenstein, in his theory, posited a principle of step migration, which according to him, Migration occurs stage by stage about rural-urban Migration (Peixoto, 2004). Nevertheless, international Migration also shows the same trend. Based on interviews, it is clear that immigrants opted by traveling by stages considering safety issues (animals within the forest, border control, information about destination places, and fear for refoulement). examining the means of travel in order to reach Mozambique shows that African immigrants did have long journeys.

\section{Table 2. Migration routes and transport used by country origin}

\begin{tabular}{|l|l|l|l|}
\hline \multicolumn{2}{|l}{$\begin{array}{l}\text { Country of } \\
\text { origin }\end{array}$} & \multicolumn{2}{l}{ Migration route } \\
\hline 1 & Burundi & Burundi-Tanzania-Mozambique & Truck, airplane and bus \\
\hline 2 & Nigeria & $\begin{array}{l}\text { Belgium-Ethiopia-South Africa- } \\
\text { Mozambique }\end{array}$ & Airplane and bus \\
\hline 3 & Rwanda & $\begin{array}{l}\text { Rwanda- Congo- Ethiopia- } \\
\text { Kenya-Mozambique }\end{array}$ & Airplane \\
\hline 4 & Senegal & $\begin{array}{l}\text { Senegal-Ethiopia- South Africa- } \\
\text { Mozambique }\end{array}$ & Airplane and bus \\
\hline
\end{tabular}

\section{CAUSES OF MIGRATION IN AFRICA}

The literature emphasizes that Migration within and outside Africa results from political and military disturbances that characterize African countries right after their independence. Civil wars likewise occurring in different regions of Africa have been the leading causes of outbound migration. Adding to this, the failure of economies of African countries and the growth of inequalities accompanied by a general lack of job opportunities are together the set of factors that either push or pull people to move. The main reasons are war, life under risk, xenophobic attacks in South Africa, job and business opportunities foreseen in Mozambique. The table below indicates the reasons for immigration to Maputo.

Causes of Migration by country of origin

\section{\# Country of origin Causes}

\begin{tabular}{|l|l|l|}
\hline 1 & Burundi & War and life in danger \\
\hline 2 & Nigeria & $\begin{array}{l}\text { War (Biafra), xenophobia attacks and business } \\
\text { destruction (South Africa) following or husbands } \\
\text { attachés and lack of job/opportunities (Belgium) }\end{array}$ \\
\hline 3 & Rwanda & $\begin{array}{l}\text { Political persecution, following or husbands atatchés, } \\
\text { lack of jobs in Rwanda, and the need to pursue } \\
\text { studies outside of Rwanda, particularly in an English- } \\
\text { speaking country such as South Africa. }\end{array}$ \\
\hline 4 & Senegal & Business opportunities \\
\hline
\end{tabular}

\section{WHY DID CHOOSE MOZAMBIQUE TO LIVE BY COUNTRY OF ORIGIN?}

Migration literature hardly mentions any migration flows from these African countries towards Mozambique. This new immigration flows is recent and started no more than 30 years. Many African Migrants have crossed several borders towards Mozambique since they have been forced to leave their places of origin and seek safety in other countries. People who have crossed Mozambican borders either entering from southern borders or northern claimed to be persecuted in their countries of origin; some were fleeing human rights violation, some repression, or any armed conflict. Most of them are caught by the police without proper documents, such as visas or DIRE (Document of Foreign Residents).

Since The following answers interpreter faithfully what, the literature says about Migration

"That is a fascinating question. I discovered Mozambique through South Africa, where I lived. I read news about Mozambique and started to gain interest. On the other hand, I studied at school the history and geography of Africa that included Mozambique. Since it was not pleasant living in South Africa anymore, I thought I would move here. I moved by making visits and realized how pleasant it was to live here than in South Africa" (Burundian, Maputo 05 August 2021)

"I like many things in Mozambique. There is peace and freedom. I can stay up late on the streets whispering with this Mozambican friend of mine where no one tells me to pick up. Only now, with Corona, we have to close the store early. I like everything here. I like the people and their friendliness" (Rwandan, Maputo 05 August 2021)

"My husband and I have lived in other African countries such as Ghana and Togo. Life was harder there than here. We learned to do business in difficult times in Ghana and Togo. The environment is more competitive there than here. Here we teach people how to do business. While in Ghana and Togo, they already do business. Nobody taught them". (Nigerian, Maputo 04 August 2021) 


\section{TYPE OF VISA THAT ALLOWED THEM TO ENTER AND SETTLED IN MOZAMBIQUE}

In Mozambique, immigration is managed by the National Service of Migration (SENAMI), created by the Law $n^{\circ}$. 4/2014, of 5 February 2014. This service is under the Ministry of Interior. The Constitution of Mozambique of 2004 and revised in 2018 approved Law no 5/93 of 28 December that establishes the juridical regime of foreign citizens, where it refers to all foreign citizens who do not own Mozambican nationality. This means that $s$ those who are not Mozambicans need permission to enter, settle, and work permits as businesses. The table below shows that the foreigners entered Mozambique with a tourist visa; some had carte blanch or travel document

Table 3. Visas that allow them to enter and be in Mozambique

\begin{tabular}{|l|l|l|}
\hline \# & Country & \multicolumn{1}{l|}{ Type of visa } \\
\hline 1 & Burundi & $\begin{array}{l}\text { Tourist visa, and some without visa. They had contacts, carte } \\
\text { blanch/travel documents. }\end{array}$ \\
\hline 2 & Nigeria & Business visa; tourist visa \\
\hline 3 & Rwanda & $\begin{array}{l}\text { Tourist visa and some without visa. They had contacts, carte } \\
\text { blanch/travel documents. }\end{array}$ \\
\hline 4 & Senegal & Tourist visa \\
\hline
\end{tabular}

Source: MIAD data basis

\section{LENGTH PERIOD OF STAY IN MOZAMBIQUE}

The study demonstrates that the length of stay varies from two months to more than 20 years, as seen in the table below.

\begin{tabular}{|l|l|l|}
\hline$\#$ & \multicolumn{1}{|l|}{ Country } & \multicolumn{1}{l|}{ Length period of stay } \\
\hline 1 & Burundi & From 2 months to 20 years \\
\hline 2 & Nigeria & From 2 to 10 years \\
\hline 3 & Rwanda & From 2 months to 12 years \\
\hline 4 & Senegal & Less than five year \\
\hline
\end{tabular}

Source: MIAG data basis

\section{CHALLENGES FACED BY AFRICAN IMMIGRANTS IN MAPUTO}

Interviewees pointed out the following challenges:

- $\quad$ Excessive demand and difficulty in migration procedures;

- $\quad$ High cost of a visa (work permit around \$800; DIRE- Residence Document for Foreigners, which costs about $\$ 600$ and is valid for one year).

- Language barriers as the National Service of Immigration translate the basic information solely into English.

- Privileges that are given to some nationalities, namely European, Americans, Asians, and tight regulations to Africans.Corruption.They came under straits as those who are applying for refugee status shall do from northern Mozambique borders and not in Maputo.Long way to arrive here and used different transport ways (boat, truck, bus, and airplane); the demand to apply for a work permit previous travel.

- In South Africa, they faced xenophobic persecution attacks and decided to move out.
Some of the commentaries and experiences on immigration challenges by interviewees are:

"There were two major problems: 1) Not mastering the Portuguese language and 2) lack of money. Everything gets difficult when one does not master the Portuguese language or any other language from one place because one does not know where to go, whom to apply for, how to get to the right place for his subject. One does not know where to submit his papers. As I said, the Portuguese language is a deterrent to many foreigners. Moreover, the staffs take advantage of us. Moreover, they do not speak English, and they do not want to learn. Even in the finance sector, they only talk Portuguese. Furthermore, we get it when they say jokes at us". (Burundi, Maputo 05 August 2020)

"I arrived in Mozambique in December 2018. I came with friends. I was in Congo for a while, where I stayed for five months. Then I went to Tanzania, and from there, I went back to Congo because I still had no way to travel to Maputo. Finally, I took an Ethiopia Airways plane to AddisAbebi in Congo, where I stayed only one day. It is not easy.

Nevertheless, I did it. I decided to come because of the political situation and the lack of employment. I did not do anything back in Rwanda. I heard about Mozambique from my brother's friend who is here in Maputo. He is the one who brought my brother to Maputo" (Rwandese, Maputo 05 August 2020)

\section{MIGRATION FOR INCLUSIVE AFRICAN GROWTH}

The paper's core is to discuss the extent to which Migration can contribute to inclusive growth in Mozambique through a case study of Maputo. There are several ways of contributing to inclusive growth. The main argument is that they create jobs for Mozambicans and pay all taxes, as seen in the following interviews quotes:

"I have this bottle store. I have two employees: a Mozambican and a Rwandan. This one's new. The former left work. My husband and I do this liquor 
business because it is a business that has much output. We sell a lot every day. This shop (container) is rent to a Mozambican. I intended to have a hair salon, but I saw that the drink is for faster profit. Mozambicans do not commit to working. They work poorly and want to receive money". (Rwanda, Maputo 05 August 2020)

Looking at activity sectors where they have engaged clearly, Africans in Maputo are engaged in small activities, as seen in the following interviews quotes:

"Yes. It contributes when immigrants pay taxes and all the fees required of us as citizens residing in the country. We pay taxes for the construction of infrastructure and schools. The problem here is corruption. We pay much money, but problems still prevail in the lack of schools, clinics, and transport. Back in Rwanda, no one travels by open box vans. These open box vans are for goods, or animals" (Rwandan, Maputo, 05 August 2020).

"We have taught Mozambicans how to run a business. They know that business is made by small profit and not to gain at once. We taught them that a client is not all those that can afford it. It is about an individual who needs your services" (Nigerian, Maputo 04 August 2020).

"We do not hire those who are highly qualified. We do hire those who want to work, especially women who want to work and to learn" (Nigerian, Maputo o4 August 2020)

"I own this boutique, and I have employed that girl who knows where and to whom she would sell the products. She is Mozambican, and she knows the potential buyers. I hired her for more than two years". (Senegalese, 07 August 2020).

\section{CONCLUSIONS}

Inclusive growth is a debatable concept, and it has been seen under government perspective as a concept that fits only in big businesses. On the contrary, inclusive growth has to do with opportunities created for all. However, it is a fact that inequalities are a brand that characterizes developing countries, including Mozambique, particularly in cities.

Maputo city, the capital of the Republic of Mozambique, has chosen to discuss the contribution of immigrants into inclusive growth, starting from the point that migrants can be the drivers of an economy.

The data from the MIAG project allowed to make this simple contribution towards understanding African migration contribution to inclusive growth. There were interviewed Rwandans, Burundians, Nigerians, and Senegalese have commonalities in defining inclusive growth. For them, they have contributed to inclusive growth in the city of Maputo through the following actions:

- Job creation for those who want to; particularly to the poor who cannot access formal labor due to their skills limitation

- They pay taxes used as investments in social infrastructures such as schools, hospitals, roads, social houses, etc.

- Services provision and service users (house rent, electricity, transport, petrol, gas, etc.)

- $\quad$ Skills offer: Business language (French, English, Swahili, Arabic, etc.)

- African migrants, regardless of the challenges they have faced, have a sentiment that they are doing more than what megaprojects give in terms of a job.

- $\quad$ African immigrants are creating opportunities for many people through their businesses. Thus, cities will be more inclusive of all city dwellers are included in benefits of the economy. 


\section{REFERENCES}

Castles, Stephen e Miller, Mark J., 2009, The Age of Migration: International population movements in the modern world. Palgrave Macmillan, New York. 4a Edition.

Chikanda, Abel and Raimundo, I. M. 2017. Informal entrepreneurship and cross-border trade between Mozambique and South Africa. African Human Mobility Review, Volume 3, N0 2 May-August

De Has, H. 2010. Migration and Development: A Theoretical Perspective. In International Migration Review (Open access https://doi. org/10.111/j.1747-7379.2009.00804.x)

Matusse, Renato, 2009, África Austral: Das Migrações Bantu à Integração Regional. Imprensa Universitária. Maputo.

Muianga, B. S. 2021. Migração e saúde: Estratégias e gestão dos cuidados de saúde e doença dos Refugiados em Maratane, Nampula, Norte de Moçambique. Unpublished $\mathrm{PhD}$ thesis. Presented and defended at Universidade Aberta.

Peixoto, João, 2004, As Teorias Explicativas das Migrações: Teorias Micro e Macro-Sociológicas. SOCIUS Centro de Investigação em Sociologia Económica e das Organizações, Instituto Superior de Economia e Gestão- Universidade Técnica de Lisboa. Lisboa, No 11/2004.

Inês Raimundo. International migration dynamics in Mozambique and natural resource exploration: Gold and forest predation. ASC-TUFS Working Papers Volume 1 (2021). http://repository.tufs. ac.jp/handle/10108/99993

Raimundo, I. M. \& Raimundo, José A., 2017. O impacto do discurso das "descobertas" dos recursos minerais no despovoamento rural de Moçambique. Guarda, Portugal. IBEROGRAFIAS, Número 13, Ano XVIII, pp137-152.

Raimundo, Inês e Raimundo, José, 2015, A migração moçambicanna na África Austral: Povoamento e formação de famílias trasnnacionais. In Território e circulação: a dinâmica contraditória da globalização. Mónica Arroyo e Rita de Cássia Ariza da Crz (Organizadoras). Annablume Editora. São Paulo.

Raimundo, I.M., Bazagari, A.M. \& Raimundo, J. A. Análise geográfica da imigração internacional em Moçambique: um estudo de caso na Cidade de Maputo. In Cenários Pós-Pandemia: Reflexões sobre o Sul Global e Outros Territórios. Paulo Roberto Baqueiro Brandão (Organização). Cultura Acadêmica Editora. São Paulo. Pp 109-162.

Rocha-Trindade, Beatriz 2015, Das Migrações às interculturalidades. Edições Afrontamento. Lisboa.

UN-Habitat- Regional and Technical Cooperation Division 2010.

Mozambique Cities profile: Maputo, Nacala, and Manica. Nairobi. 
Notes 